\title{
ACHIEVEMENT IN MATHEMATICS AMONG IX STANDARD STUDENTS IN TRICHY DISTRICT
}

\author{
Dr. A. Edward William Benjamin \\ Research Supervisor, \\ Dept. of Education, \\ Bharathidasan University, \\ Tiruchirappalli, TamilNadu
}

\author{
P.Murugaraju \\ $\mathrm{Ph}$. D Research scholar, \\ Dept. of Education, \\ Bharathidasan University, \\ Tiruchirappalli, TamilNadu
}

Article DOI URL: https://doi.org/10.36713/epra6641

DOI NO: 10.36713/epra6641

\begin{abstract}
Acquiring Mathematics knowledge is an important factor in the achievement of the students. Learning Mathematics provides students with skill to analyze, explain, predict and find methodological solution to the problems they might face. Same students may have poor capacity to catch which may be due to several factors such as family background, economic status, education of the parents etc. Individual difference also play vital role in learning Mathematics. Achievement in Mathematics differs from type of schools, gender and locality etc. The present article aims at assessing the achievement in Mathematics among IX standard students in Trichy District. A survey method has been adopted with 90 samples from various type of schools. The investigator collected achievement score of Mathematics of IX standard students from selected schools. By applying proper statistical techniques it is proved that there is significant different in the study.
\end{abstract}

KEY WORDS: Achievement, Mathematics, IX Standard Students

\section{INTRODUCTION}

Mathematics is a basic subject in the curriculum upto high school level. It is the basic of all scientific activities. A Mathematics student develops his capacity of generalize from given statements, Critical observance of facts, functional thinking, logical reasoning, convergent and divergent thinking etc.

The National Policy on Education (1986) points out, the important of Mathematics in general education and suggests that "Mathematics should be visualized as the vehicle to train a child to think, analyses and articulate logically".

Therefore, it is imperative to find out the achievement in Mathematics among high school students. This reminds the investigator to select the problem as, "Achievement in Mathematics among high school students in Trichy District”.

\section{REVIEW OF RELATED LITERATURE}

Ritu Chandra and Dr. (Prof.) Sheikh Azimmudin study on the "Influence of Intelligence and Gender on Academic Achievement of Secondary School Students of
Lucknow City". In this Research, Researcher finds out the influence of gender on academic achievement of secondaiy school students and the influence of intelligence on academic achievement of secondary school students. For this research, Researcher used survey method and collected 614 samples (Male 358, Female 256) applying multistage sampling method. Researcher selected G.C.Ahuja Group Test of Intelligence for assessment of Intelligence by Dr. G.C.Ahuja (2008) and Socio-economic Status scale for assessment of (SES) Socio-economic status by Dr. Meenakshi (2004) were used as a tool. Finally the result of the study shows that the High IQ child will score better than the Low IQ child. Low IQ child will be a slow learner. A child with high IQ is fast learner. He will understand, grasp and learn the concepts in a better way. Academic performance needs intelligence.

Hafiz Muhammad Waqas Rafiq and four others study on I "Parental Involvement and Academic Achievement; A Study on Secondary School Students of Lahore, Pakistan". In this Research, Researcher find out the extent of parental involvement in academic activities of 
their children studying in secondary level classes and the extent of academic achievement of children studying in secondary level classes. Researcher used survey method and collected 375 samples applying multistage sampling method. Researcher selected a Questionnaire tool and finally Researcher found that - of the respondents whose parents were moderately involved in their academic activities, their relative majority $(48.6 \%)$ also moderately performed academically. It led to conclude that higher and moderate level of parental involvement in their children's academic activities correspondingly contributed in higher and moderate level of academic activities of their children respectively. Hence the analysis of data and chi-square test upheld the research hypothesis that: More the parental involvement in their children's, academic activities, the higher the level of academic achievement of children.

K. Premalakshmi in her study
"STUDY HABITS AND ACADEMIC
ACHIEVEMENT OF HIGHER SECONDARY
STUDENTS" to find out the level of Study Habits
of Higher Secondary Students and the relationship
between study habits and academic achievement of
higher secondary students. For this research,
Researcher used survey method and collected 525
samples applying multistage sampling method.
Researcher selected personal Data sheet and a
Questionnaire tool and finally Researcher found
that - the variable Study Habits is contributing for
the Academic Achievement.

Deepa Franky and S.Chamundeswari study on "Psycho-social correlates of academic achievement of students", in this Research, Researcher find out the adjustment pattern And socio-economic status influences the academic achievement of students. Researcher used survey method and collected 96 samples applying multistage sampling method. Researcher selected the Questionnaires tool, namely, Adjustment Pattern Inventory (Bhattacharya and others, 1967) and Vasanthi $s$ Adaptation of Kuppuswami s Socio-Economic Scale (Vasanthi, 1991) and finally Researcher found that - that though adjustment pattern and socio-economic status are significantly positively correlated with each other, adjustment pattern does not correlate significantly with academic achievement. On the other hand, socioeconomic status and academic achievement are positively correlated with each other significantly.

\section{NEED FOR THE STUDY}

Mathematics is regarded as the mother of all science. Mathematics is the only subject that encourages and develops logical thinking. It enables the students to discriminate between essential and non- essential. A major reason for children doing less well in school mathematic seems to be the way the subject in taught in school in India at the primary level. The class room teaching is completely diverted form their everyday and knowledge. The scientific development not understands unless we have a mathematic bent or some basic knowledge of subject.

Applied Mathematics is necessary in all walks of life. Even layman requires some amount of mathematics to live in this world. Even if one does not study mathematics as a school discipline one will have to make use of it in everyday transaction. In buying and selling, in work, in play, in entertainment, etc., require application of Mathematics.

Mathematics today is the key to learning of science. Mathematics has values called utilization, disciplinary and cultural values of education. The main reason for studying mathematics to an advanced level is that is interesting and enjoyable. People like its challenge, its clarity and the fact that you know when you all right. The solution of a problem has an excitement and satisfaction.

\section{OBJECTIVES OF THE STUDY}

$>$ To study the achievement in Mathematics among IX Standard Students with regard to type of the schools.

$>$ To study the achievement in Mathematics among IX Standard Students with regard to gender.

$>$ To study the achievement in Mathematics among IX Standard Students with regard to locality.

\section{HYPOTHESES OF THE STUDY}

1. There is no significant difference between achievement in Mathematics among IX Standard Students with regard to type of the schools.

2. There is no significant difference between achievement in Mathematics among IX Standard Students with regard to gender.

3. There is no significant difference in between achievement in Mathematics among IX Standard Students with regard to locality.

\section{METHODOLOGY AND SAMPLE SOURCES}

The Investigator has adopted normative survey method for this study. All the students IX standard in the district of Trichy were considered the population of this study. A sample of 90 students was selected from different schools in Trichy District by using stratified random sampling method.

Tool

'Mathematical Achievement Scale' (2020) was constructed and validated by the investigators. 
EPRA International Journal of Multidisciplinary Research (IJMR) - Peer Reviewed Journal

Volume: 7 | Issue: 4 | April 2021|| Journal DOI: 10.36713/epra2013 || SJIF Impact Factor 2021: 8.047 || ISI Value: 1.188

TESTING THE HYPOTHESES Hypothesis-1
There is no significant difference between achievement in Mathematics among IX standard Students with regard to type of the schools.

Table-1: Difference between the achievement in mathematics among IX standard students with regard to type of the schools

\begin{tabular}{|c|c|c|c|c|c|}
\hline Categories & $\mathbf{N}$ & Mean & SD & t-value & Remarks \\
\hline Govt. & 30 & 39.75 & 6.63 & \multirow{2}{*}{0.16} & \multirow{2}{*}{ NS } \\
\hline Govt. Aided & 30 & 39.61 & 7.84 & & \\
\hline Govt. & 30 & 39.75 & 6.63 & \multirow{2}{*}{5.76} & \multirow{2}{*}{ S } \\
\hline Matriculation & 30 & 21.43 & 5.50 & & \\
\hline Govt. Aided & 30 & 39.61 & 7.84 & \multirow{2}{*}{0.30} & \multirow{2}{*}{ NS } \\
\hline Matriculation & 30 & 21.43 & 5.50 & & \\
\hline
\end{tabular}

From table -1 , the t-value is found to be 0.16 and it is lower than the table value of 1.96 at 0.05 level. It is concluded that there is no significant difference between government and government aided school students in their Achievement in mathematics.

The calculated t-value 5.76 which is significant at 0.05 level. It is concluded that there is a significant difference between govt. and matriculation school students in their Achievement in mathematics.

The calculated t-value 0.30 which is not significant at 0.05 level. It is concluded that there is no significant difference between govt. and matriculation school students in their Achievement in mathematics.

Therefore the null hypothesis is rejected. It is concluded that there is a significant difference between the achievements of Mathematics among high school students with regard to type of the schools.

\section{Hypothesis-2}

There is no significant difference between achievement in Mathematics among IX Standard Students with regard to gender.

Table - 2: Difference between the achievement of Mathematics among IX standard students with regard to Gender

\begin{tabular}{|c|c|c|c|c|c|}
\hline Categories & $\mathbf{N}$ & Mean & SD & t-value & Remarks \\
\hline Male & 47 & 33.86 & 4.27 & \multirow{2}{*}{0.17} & NS \\
\hline Female & 43 & 33.93 & 4.09 & & \\
\hline
\end{tabular}

From table-2, the calculated t-value 0.17 which is not significant at 0.05 level. Therefore the null hypothesis is accepted. It is concluded that there is no significant difference between Male and Female students in their achievement in mathematics.

\section{Hypothesis-3}

There is no significant difference in between achievement in Mathematics among IX Standard Students with regard to locality.

Table - 3: Difference between the achievements of Mathematics among IX standard students with regard to locality

\begin{tabular}{|c|c|c|c|c|c|}
\hline Categories & $\mathbf{N}$ & Mean & SD & t-value & Remarks \\
\cline { 1 - 3 } Rural & 40 & 33.63 & 4.39 & \multirow{2}{*}{1.28} & NS \\
\cline { 1 - 3 } Urban & 50 & 34.30 & 3.83 & & \\
\hline
\end{tabular}

From table-3, the calculated t-value 1.28 which is significant at 0.05 level. Therefore the null hypothesis is accepted. It is concluded that there is no significant difference between rural and urban students in their achievement in mathematics.

\section{FINDINGS OF THE STUDY}

1. There is no significant difference between government and government aided school student in their achievement in Mathematics. 
EPRA International Journal of Multidisciplinary Research (IJMR) - Peer Reviewed Journal

Volume: 7 | Issue: 4 | April 2021|| Journal DOI: 10.36713/epra2013 || SJIF Impact Factor 2021: 8.047 || ISI Value: 1.188

2. There is significant difference between government and Matriculation school student in their achievement in Mathematics.

3. There is no significant difference between government aided and Matriculation school students in their achievement in Mathematics.

4. There is no significant difference in achievement in Mathematics of IX standard students in terms of gender.

5. There is no significant difference in achievement in Mathematics of IX standard students in terms of locality.

\section{CONCLUSION}

The present study provides to know the achievement in Mathematics among IX standard students. After finishing the statistical analysis Researcher has reached in the generalization. The final results reveal that there is a significant difference between Govt.and Matriculation schools students in their achievement in Mathematics. There is no significant difference between other type of schools students in their achievement in Mathematics. Also it reveals that there is no significant difference in achievement in Mathematics among IX standard students in terms of gender and locality. This study will help the teachers to Plan and improve the achievement in Mathematics among IX standard students.

\section{REFERENCE}

1. Chandra Ritu \&. (Prof.) Azimmudin Sheikh. Influence of Intelligence and Gender on Academic Achievement of Secondary School Students of Lucknow City". IOSRJHSS, 2013. 17(5):09-14. ISSN- 22790837.

2. Franky Deepa, Chamundeswari S. Psycho-social correlates of academic Achievement of students. Ins. J. Curr. Res. Aca. Rev; 2014, 2, 148-158. ISSN-23473215.

3. Rafiq Hafiz MW, Fatima Tehsin, Saleem Muhammad, Ali Khan. M. Parental Involvement and Academic Achievement; A Study on Secondary School Students of Lahore, Pakistan. IJHSS, Special Issue, USA. 2013, 3(8).

4. Premalakshmi.K. Study Habit and Academic Achievement of Higher Secondary Students. Periyar University, Salem, 2012, 1(3). ISSN- 2278- 8808.

5. John W.Best \& James V.Khan (1992), Research in Education, New Delhi: Eurasia publishing House.

6. Aggarwal, J.C (1996), Education Research and Instruction, New Delhi: Arya Books Depot.pp.88,89.

7. Kothari, C.R (1998) Research Methodology, New Delhi : Vishwa prateashan pvt.Ltd
8. Mangal, S.K (2005), Statistics in psychology and Education, New Delhi: Prentice Hall of India Pvt.Ltd.

9. http//www.news.week.education.com

10. education.vw.edu

11. www.indian research journal.com 